\title{
2020 Drought in New England
}

$\mathrm{B}$ elow average and infrequent rainfall from May through September 2020 led to an extreme hydrologic drought across much of New England, with some areas experiencing a flash drought, reflecting its quick onset. The U.S. Geological Survey (USGS) recorded record-low streamflow and groundwater levels throughout the region. In September, the U.S. Department of Agriculture (2020) declared Aroostook County in Maine and Hillsborough and Merrimack Counties in New Hampshire as crop disaster areas. By the beginning of October, 166 community water systems and 5 municipalities in New Hampshire, more than 100 municipalities in Massachusetts, and several community water supplies in Connecticut, Maine, and Rhode Island had mandatory water restrictions in place (Northeast Regional Climate Center, 2020b).

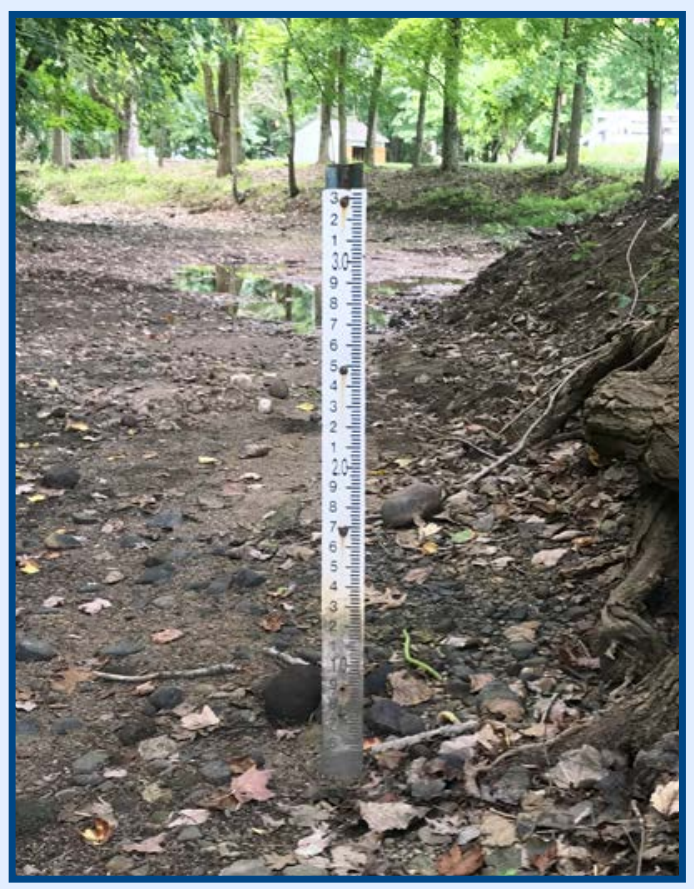

\section{Highlights}

- Much of the scarce precipitation during summer 2020 fell in a few storms, leaving long periods with little to no rain.

- Northern and central Maine were in a flash drought by the beginning of July; southeastern Massachusetts, northern Rhode Island, and northeastern Connecticut, by the beginning of August.

- During September, 14 USGS streamgages recorded the lowest 7-day average streamflows in the past 30 years; the USGS recorded the lowest streamflow measurements in the past 30 years at 14 streamgages.

- The lowest monthly groundwater levels in the past 25 years were recorded at 24 USGS monitoring wells during the summer.

Photograph of a dry stream channel at Mill River at Cook Hill Road near Cheshire, Connecticut, at U.S. Geological Survey streamgage 01196588 on September 3, 2020; photograph by Narcyz Dubicki, USGS.

Photograph of Kingsbury Stream at Abbot Village, Maine, from U.S. Geological Survey streamgage 01031450 on September 29, 2020; photograph by Andrew Cloutier, USGS. 


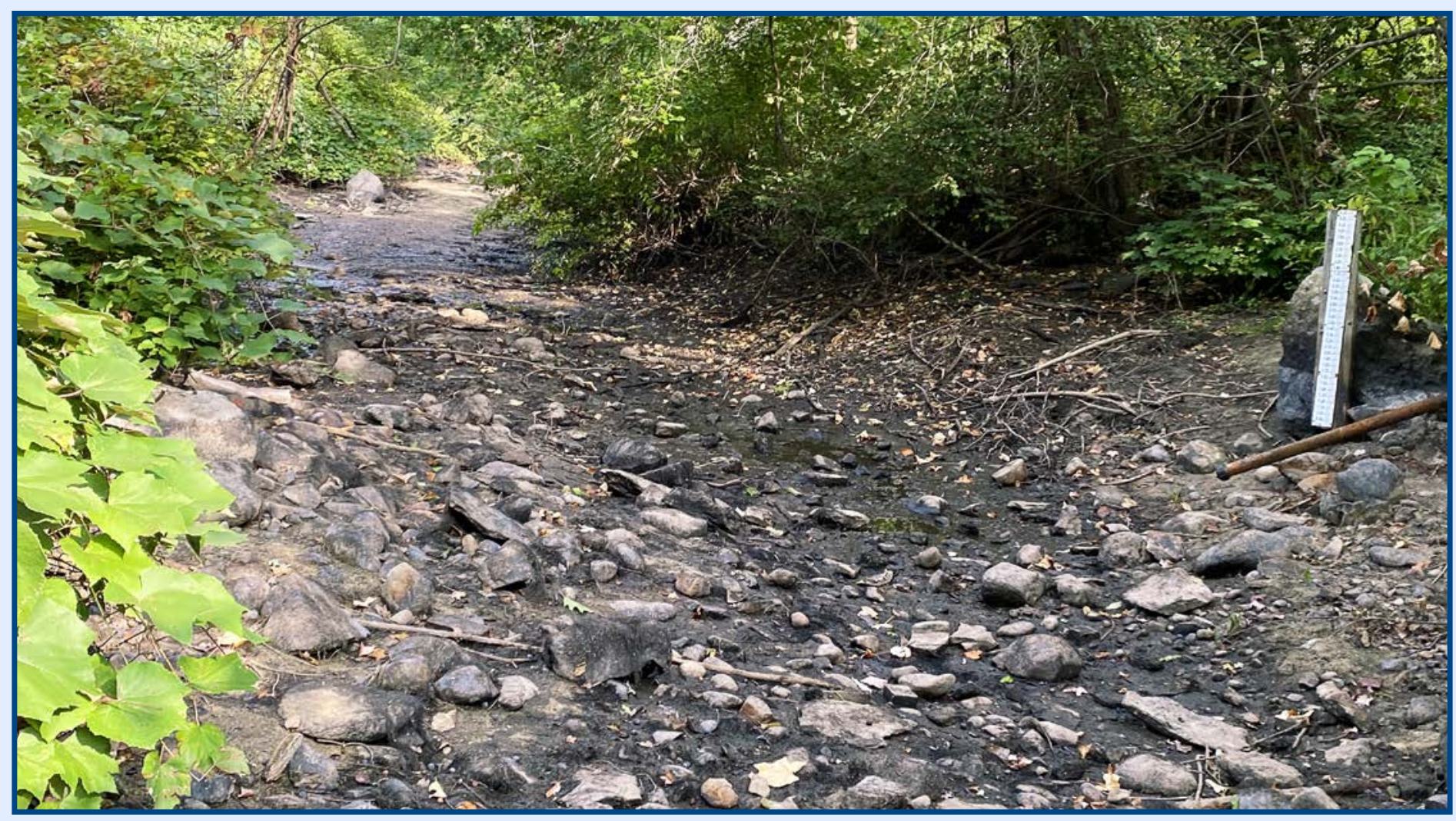

Photograph of a dry stream channel at the Segreganset River near Dighton, Massachusetts, at U.S. Geological Survey streamgage 01109070 on September 17, 2020; photograph by Casey Beaudoin, USGS.

\section{Study Area}

Data from 76 streamgages and 121 wells (fig. 1) were used to characterize the hydrologic drought in New England in 2020. Elevations in New England range from 0 feet (ft; sea level) relative to the North American Vertical Datum of 1988 (NAVD 88) at the coastline to $6,288 \mathrm{ft}$ NAVD 88 at the top of Mount Washington in New Hampshire. In much of the region, the river valleys consist of sand and gravel deposits, and the upland areas, of till deposits. Glacial deposits overlay carbonate-rock, sandstone, and crystalline rock. Average annual precipitation ranged from 36 to 60 inches (in.) in New England for the 30-year period 1981 through 2010 (National Oceanic and Atmospheric Administration, 2020d; PRISM Climate Group, 2020). Although precipitation is generally well distributed throughout the year, the lowest streamflows tend to be in the late summer and fall.

\section{Drought Definitions}

Drought is defined by its spatial extent, intensity, magnitude, and duration; the components of the hydrologic cycle it affects; and the systems that it affects. For example, a meteorological drought is defined by below-average precipitation, whereas an agricultural drought is defined by below-average soil moisture at a time critical to crop development. Hydrologic droughts are characterized by below-average streamflow or groundwater levels and typically lag meteorological and agricultural droughts; a flash drought is defined by how quickly drought conditions intensify. Socioeconomic droughts occur when the demand for goods exceeds supply as a result of shortfalls in water supplies, and ecological droughts are prolonged and widespread deficits in water supplies that create stresses across multiple ecosystems (National Drought Mitigation Center, 2020). Although the 2020 drought in New England included all the above listed types of drought at different times and to different geographic extents between May and September, this publication highlights the hydrologic drought during this period.

\section{Drought Severity}

Each of the New England States defines drought levels differently, using different criteria for drought declaration (National Drought Mitigation Center, 2020). The U.S. Drought Monitor characterizes drought similarly across the States using five categories: abnormally dry, moderate drought, severe drought, extreme drought, and exceptional drought. The U.S. Drought Monitor reported that dry conditions started in New England in mid-May, and approximately 17 percent of New England was abnormally dry by early June. By early July, 50 percent of New England was abnormally dry, and 40 percent was in a moderate drought. Though intermittent rain events in July caused temporary improvement, by the end of September, all of New England was in a drought, with parts or all of 23 counties in extreme drought (National Drought Mitigation Center, 2020). Extreme drought includes widespread crop loss, modified recreation and hunting, extremely reduced flow to no flow in streams, and increased well drilling and bulk water hauling; extreme droughts would be expected to happen on average once every 20 to 50 years (Svoboda and others, 2002).

Some regions in New England met the definition for a flash drought, which is defined by Otkin and others (2018) as at least a two-category worsening in the U.S. Drought Monitor during a 4-week period or a three-category worsening during 


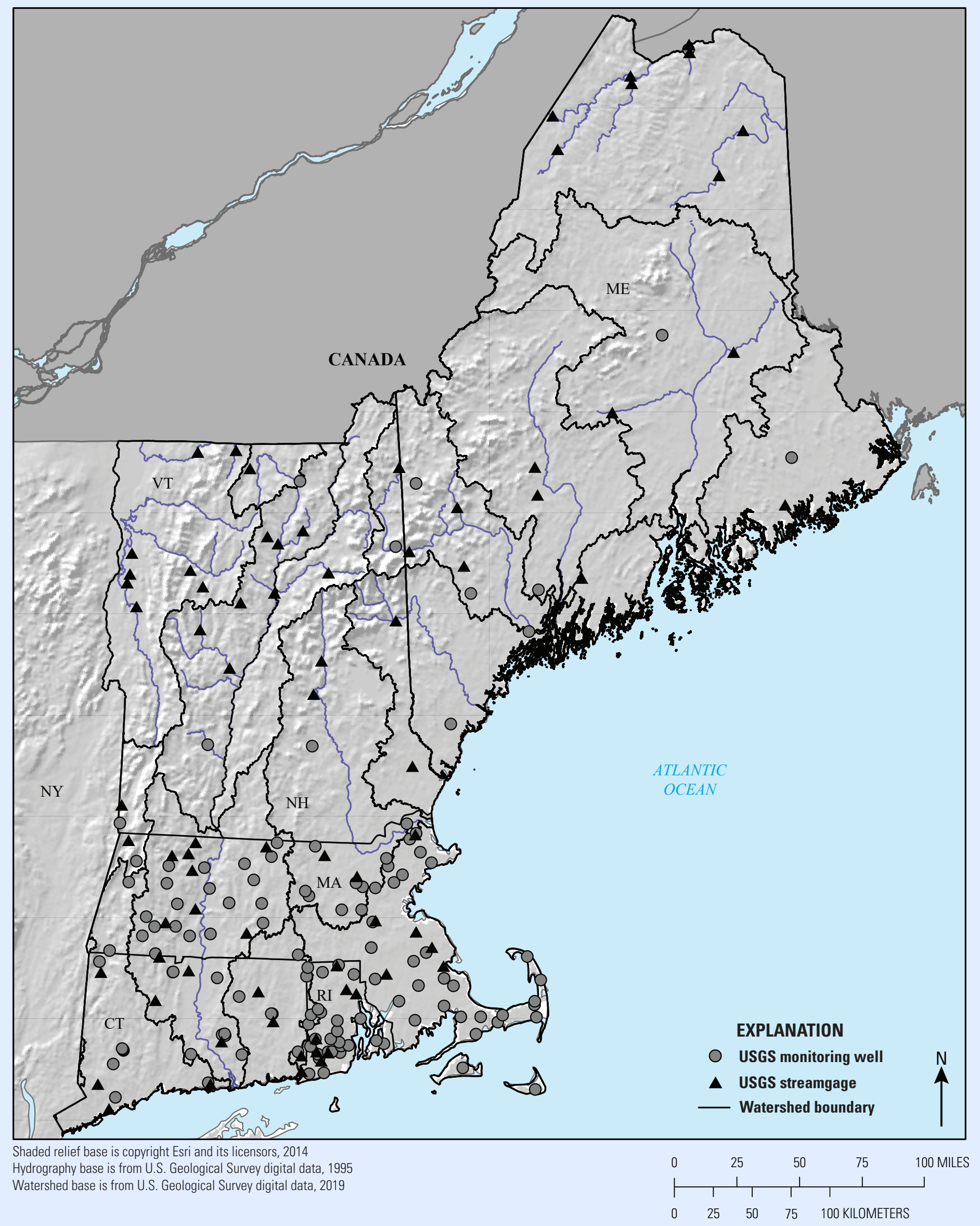

Figure 1. Map showing locations of U.S. Geological Survey (USGS) streamgages and monitoring wells in New England used for drought analyses for 2020. 
an 8-week period. Northeastern and central Maine went from no drought on June 9 to moderate drought on June 23 and then to severe drought by July 7; the severe drought persisted for 12 weeks. Conditions in a part of northeastern Maine progressed to an extreme drought in September and remained there through September 30. Southeastern Massachusetts, northern Rhode Island, and northeastern Connecticut also met the definition for a flash drought when conditions progressed from abnormally dry on July 28 to severe drought on August 18 where they stayed for 6 weeks. Conditions in parts of southeastern Massachusetts and Rhode Island progressed to extreme drought on September 15 (National Drought Mitigation Center, 2020). The evaporative demand drought index indicated that the 12-week period ending on September 30 was in the most severe drought category (ED4) for parts of all six New England States (National Oceanic and Atmospheric Administration, 2020b).

\section{Meteorological Drought}

\section{Snowpack}

For much of the winter and spring, snow water content in northern Maine was among the highest of the past 10 years. Eastern coastal Maine and southern Maine, however, had snow water content in the lowest 10 - to 25 -percent of the past 10 years from January through April (Maine Geological Survey, 2020). New Hampshire had below-average snow water content from the end of January through March for the 25 to 70 years of record (New Hampshire Department of Environmental Services, 2020).

\section{Temperatures}

During June, July, and August, temperatures were from 1 to 6 degrees Fahrenheit $\left({ }^{\circ} \mathrm{F}\right)$ warmer than average for the 1981-2010 period of record throughout New England (National Oceanic and Atmospheric Administration, 2020c). Maine experienced its warmest summer on record. July was the warmest month on record in Portland, Maine $\left(73.7^{\circ} \mathrm{F}\right)$, the second warmest month on record in Caribou, Maine $\left(69.9^{\circ} \mathrm{F}\right)$, and the third warmest month on record in Concord, New Hampshire $\left(74.5^{\circ} \mathrm{F}\right)$; temperatures were also $6.2^{\circ} \mathrm{F}$ above average $\left(76.8^{\circ} \mathrm{F}\right)$ in Burlington, Vermont, and more than $4^{\circ} \mathrm{F}$ above average in much of Rhode Island, Connecticut, and Massachusetts.
Minimum daily temperatures at the Burlington airport remained above $60{ }^{\circ} \mathrm{F}$ for the 41 days from June 26 to August 5 .

\section{Rainfall}

Total precipitation deficits (departures from averages computed from 1981 to 2010) from May through September 2020 throughout New England ranged from 3 in. below average in Burlington to 12.5 in. below average in Hartford, Connecticut. In Maine, New Hampshire, Massachusetts, and Rhode Island, total precipitation deficits were between 7.3 and 8.7 in. below average for this 5-month period. Aroostook County in Maine recorded the second driest summer (54 percent of average), with only 6.16 in. of precipitation from June through August (National Oceanic and Atmospheric Administration, 2020c, d). The 3-month period from July though September was the driest on record in Rhode Island (National Oceanic and Atmospheric Administration, 2020a).

Much of the rain that did fall during summer 2020 fell during a few large storms, leaving long periods with little to no rain. For example, there were 42 consecutive days from May 16 through June 27 with a total of 0.28 in. of rain in Concord (fig. 2) and 0.38 in. in Portland, the driest periods on record for these dates. Until the last 2 days of September, the month's rainfall would have set records throughout the region, with $0.07 \mathrm{in}$. recorded in Bangor, Maine, and 0.26 in. falling in Concord from September 1 through 28 (National Oceanic and Atmospheric Administration, 2020c).

\section{U.S. Geological Survey Streamflow and Groundwater- Level Monitoring Networks in New England}

The USGS operates 76 streamgages throughout New England on streams that are relatively unaffected by water withdrawals, wastewater discharges, or diversions or dams and that have continuous data for at least the past 30 years (October 1991 through September 2020; fig. 1; table 1.1); USGS staff collected more than 300 supplemental streamflow measurements during summer 2020 to document the drought. The stage (gage height) of the river is typically measured at 5- to 15- minute intervals and is then transmitted by telemetry to the USGS National Water Information System (NWIS; U.S. Geological Survey, 2020). Streamflow is computed based on the correlation

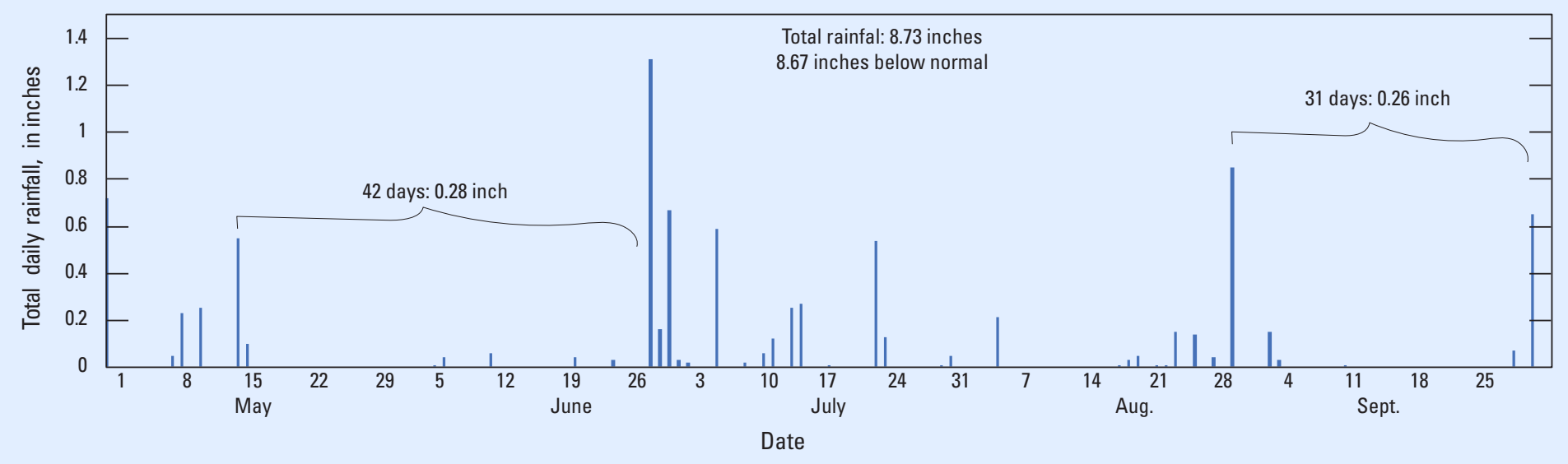

Figure 2. Graph showing total daily rainfall from May 1 through September 30, 2020, in Concord, New Hampshire; data are from National Oceanic Atmospheric Administration (2020c). 


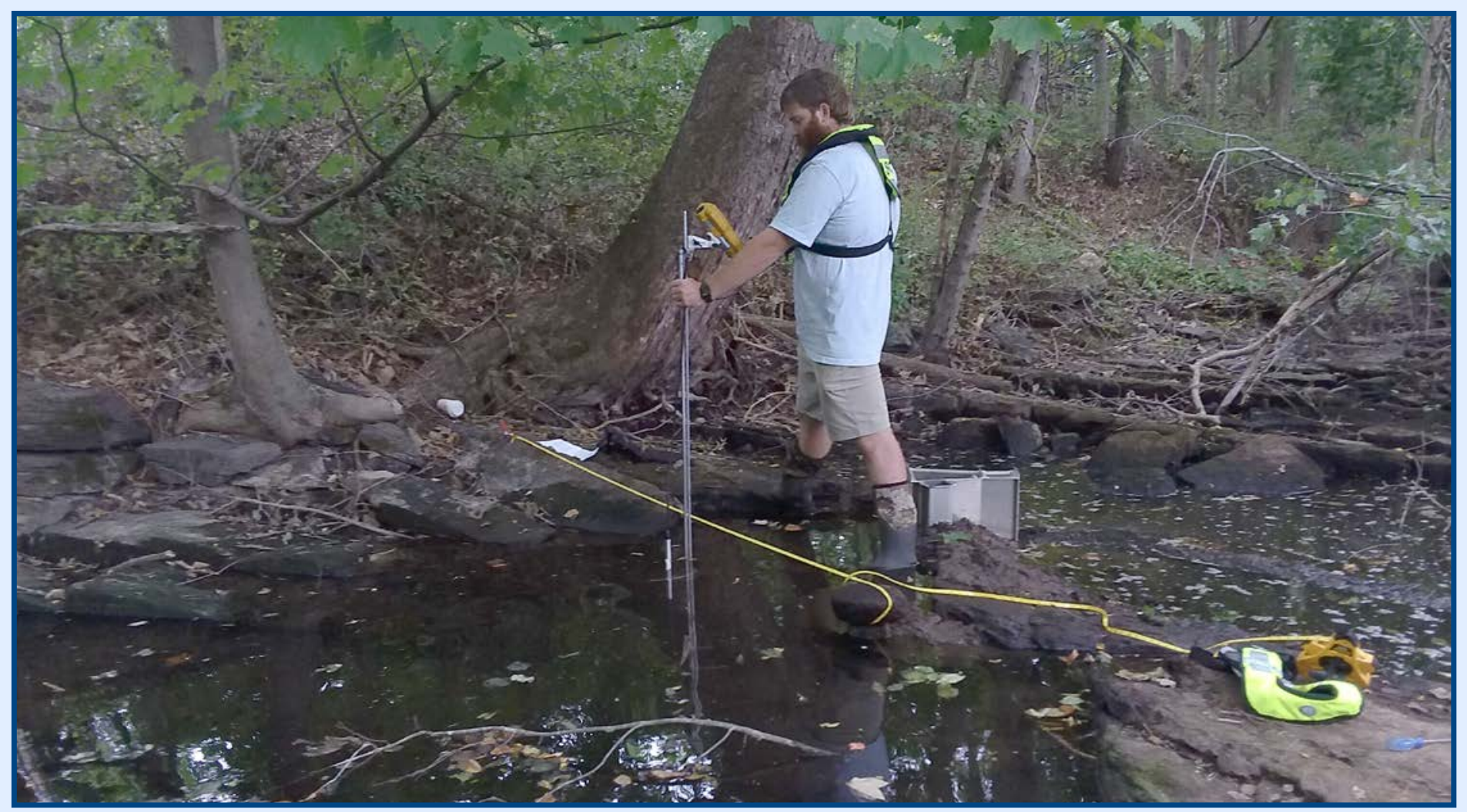

Photograph of streamflow measurement at Stony Brook near West Suffield, Connecticut, at U.S. Geological Survey streamgage 01184100 on September 18, 2020; photograph by Nigel Pepin, USGS.

between streamflow measurements and the concurrent stage at each streamgage, allowing for near real-time estimates based on the incoming stage data (Rantz and others, 1982; Turnipseed and Sauer, 2010).

The USGS operates 121 monitoring wells throughout New England that have at least 25 years of record (October 1996 through September 2020; fig. 1; table 1.2). Although a minimum of 30 years of record is typically used for long-term averages, there are very few wells with 30 years of record in certain areas in New England. The wells used in the analysis were typically shallow-depth wells (9.6 to 110 feet) and were completed in either glacial sand and gravel deposits or till deposits; wells completed in bedrock were excluded. Of the wells used in the analysis, 63 are measured periodically, generally once per month, based on protocols described by Cunningham and Schalk (2011). The remaining 58 wells are monitored in real time, and the water level is recorded hourly or more frequently; the data are transmitted by telemetry to NWIS (U.S. Geological Survey, 2020). For consistency among groundwater levels, monthly

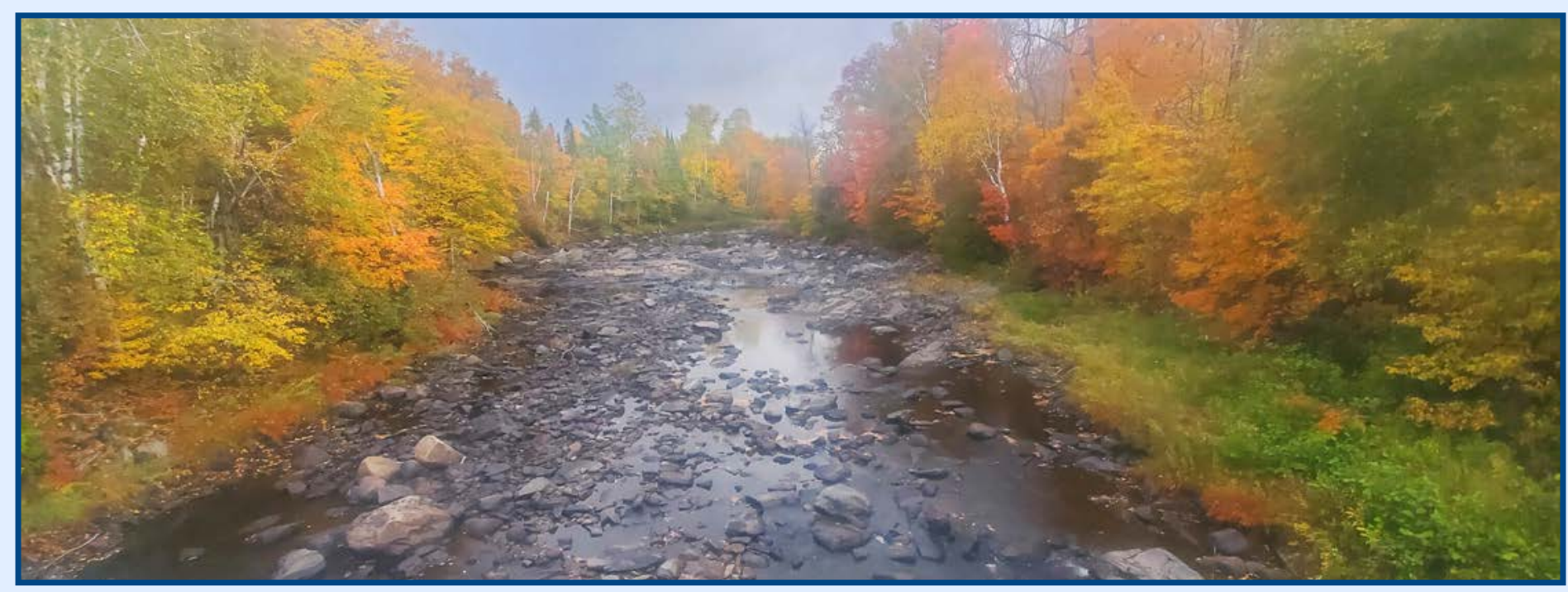

Photograph of the Piscataquis River near Blanchard, Maine, at U.S. Geological Survey streamgage 01031300 on September 29, 2020; photograph by Andrew Cloutier, USGS. 
periodic measurements were used for both real-time and periodically measured wells except when a periodic measurement was missing; when a periodic measurement was missing, a daily mean water level on the median day of the month the well was typically measured served as the measurement for that month.

\section{Data Analysis}

Drought conditions from May to September were evaluated with 7-day streamflows at the 76 streamgages used to calculate daily-streamflow percentiles and with monthly groundwater levels at the 121 wells used to calculate monthly groundwaterlevel percentiles. For this report, the 7-day streamflow refers to the average at a single site of the seven daily streamflows leading up to the day referenced, and the average 7-day streamflow refers to the average 7-day streamflow across multiple sites in a watershed or across New England. Percentiles for streamflows were calculated using water years ${ }^{1} 1991$ to 2020 , and for groundwater levels, water years 1996 to 2020 . The 25 th to 75 th percentiles indicate average conditions, percentiles greater than 75 percent indicate conditions wetter than average, and percentiles less than 25 percent indicate conditions dryer than average. Percentiles were also averaged across six-digit hydrologic unit code watersheds to highlight trends across New England.

${ }^{1}$ A water year is defined as the 12-month period from October 1 through September 30 of the following year and is designated by the calendar year in which it ends.

\section{Hydrologic Drought of 2020}

\section{Streamflow Conditions}

Streamflows were at average levels during winter and spring 2020. Streamflows rapidly declined during May and remained low for the duration of the summer. On May 1, 7-day streamflows were at or above average at most streamgages across New England. By June 3, 7-day streamflows had dropped to below average at 54 percent of streamgages in New England. The average 7-day streamflow percentile for the 76 streamgages ranged from a high of the 75th percentile on May 6 and 7 to a low of the 6th percentile from September 23 through 28 (fig. 3) and was below average from June 5 to 29, August 2 to 3, August 13 to 29 , and September 10 to 30 .

A drought in 2016 had affected large areas of New England and resulted in record low streamflows at some USGS streamgages (Northeast Regional Climate Center, 2020a). Data for four representative streamgages (fig. 4) with more than 70 years of record show streamflows in May 2020 being higher than in May 2016. However, at three of the four streamgages (fig. $4 A, C$, and $D$ ), streamflow in June 2020 dropped below that of June 2016, and at all four streamgages, streamflow in late September 2020 dropped below that of September 2016. Two of the four streamgages (fig. 4B and $C$ ) had record low flows in September 2020.

In New England, mean monthly streamflows were lowest relative to average during June, August, and September, but not

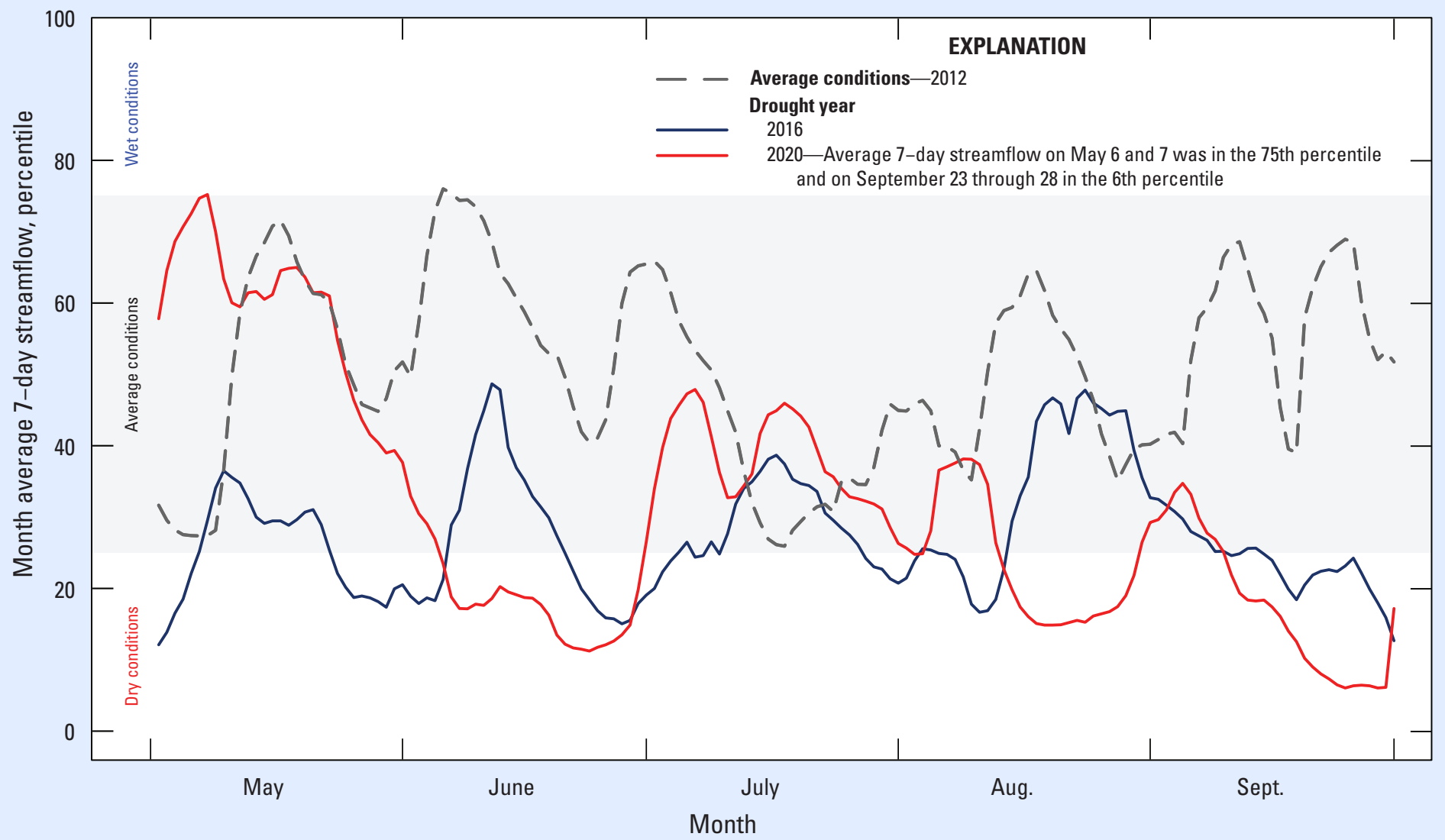

Figure 3. Graph showing the average 7-day streamflow percentile for 76 streamgages in New England from May 1 through September 30 in 2012 (representative of average conditions), 2016 (drought), and 2020 (drought) compared with average conditions from 1991 to 2020. 

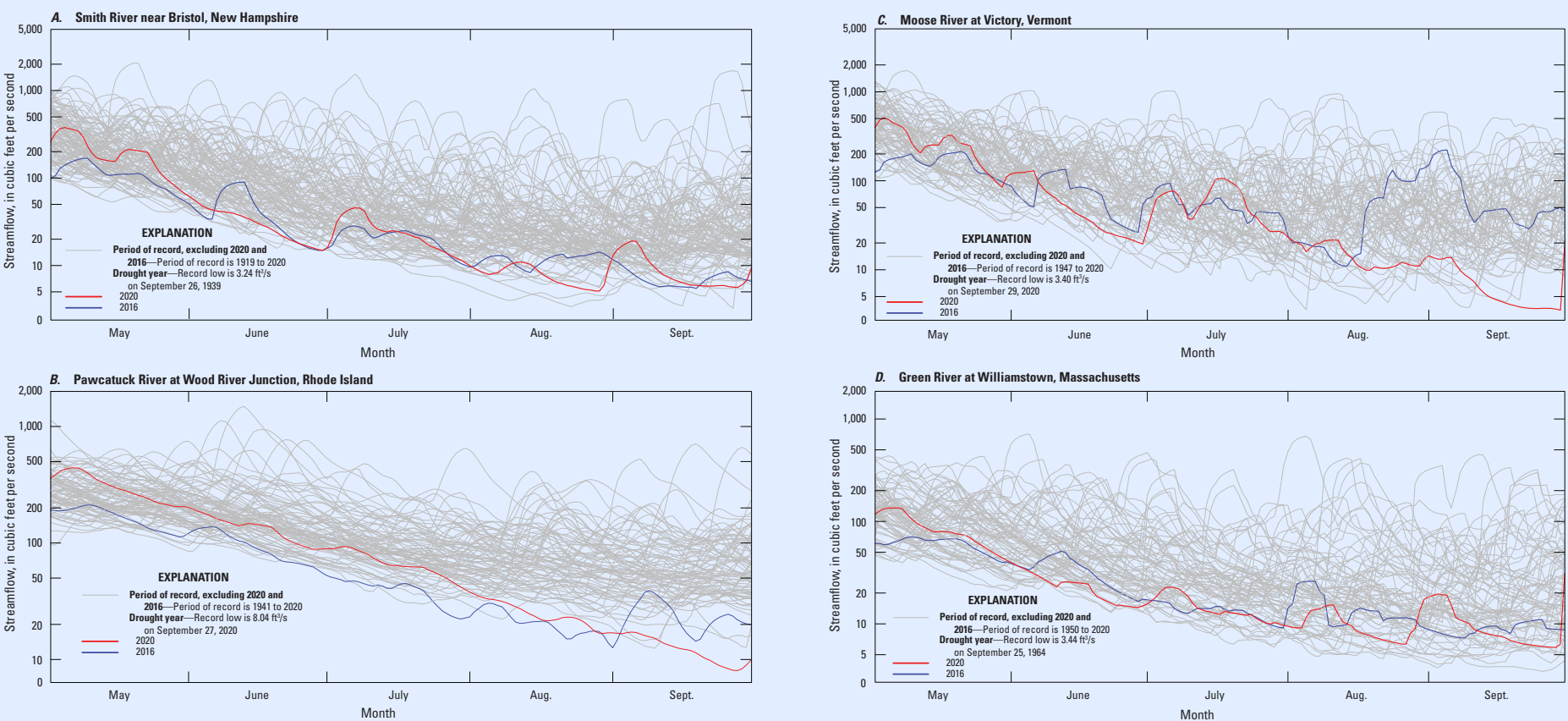

Figure 4. Graphs showing the moving average 7-day flows at four streamgages in New England from May through September for their period of record. A large version of the figure is available at https://doi.org/10.3133/ofr20201148.

all areas followed this pattern (fig. $5 A$ ). In southeastern Massachusetts and Rhode Island, mean streamflows in June were near average, with streamflow at only 5 of 15 streamgages below the 25 th percentile, while most streamflows elsewhere in the region were below the 25 th percentile. In northern Maine, mean streamflows in July were below the 10th percentile, with three of eight sites recording a 30-year low in mean streamflow in July, while in the rest of New England, mean streamflow in July was near average. In extreme northern Vermont, mean streamflows in August were average, while in the remainder of New England, it was below average.

\section{Groundwater Conditions}

During 2020, groundwater levels throughout New England had a slower and more gradual decline than streamflows.

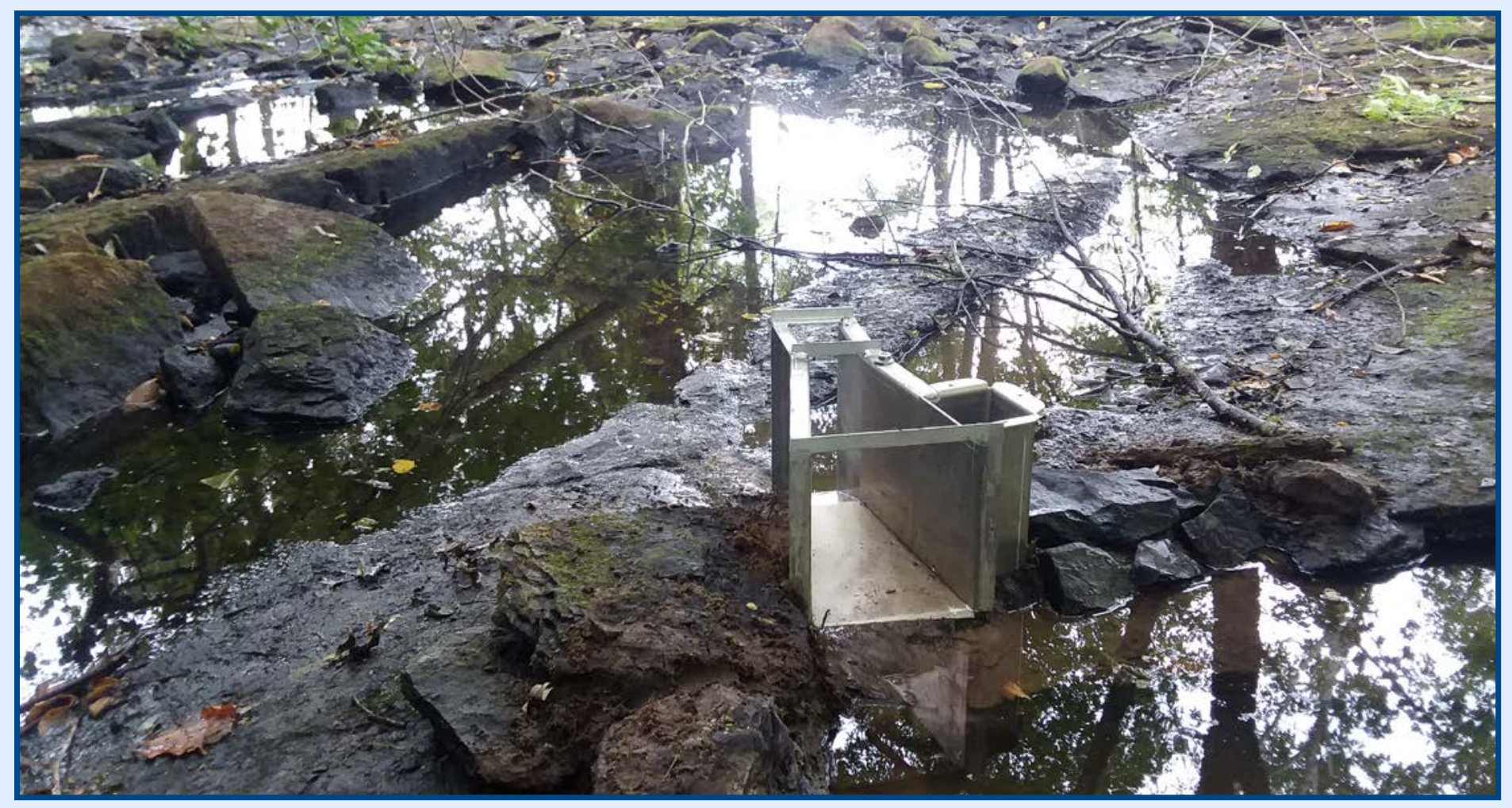

Photograph of the lowest streamflow measurement made for the period of record using a Parshall flume at Stony Brook near West Suffield, Connecticut, at U.S. Geological Survey streamgage 01184100 on September 18, 2020; photograph by the Nigel Pepin, USGS. 

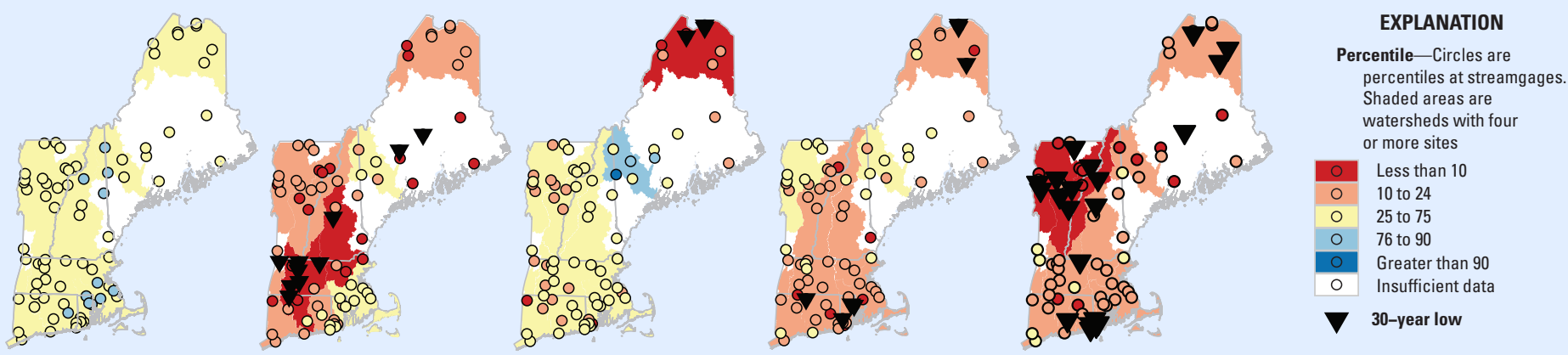

B. Monthly groundwater level percentile at $\mathbf{1 2 1}$ monitoring wells

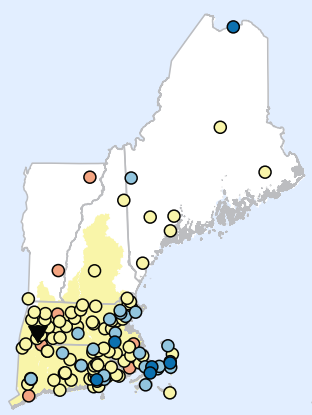

May

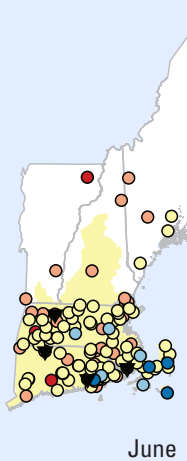

June o

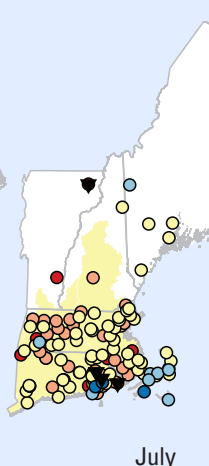

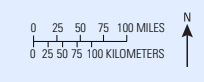

8

30-year low

Figure 5. Maps showing $A, 30$-year percentile for mean monthly streamflow at 76 streamgages and $B, 25$-year percentiles of monthly groundwater levels at 121 wells. Watersheds are based on the six-digit hydrologic unit code boundaries from U.S. Environmental Protection Agency and U.S. Geological Survey (2012); watersheds with four or more sites are shaded according to the mean percentile across those sites. A large version of the figure is available at https://doi.org/10.3133/ofr20201148.

Although groundwater levels typically lag streamflows and show less variability in the declines during the growing season because of limited recharge, the rate of decline was faster in 2020 for several wells than in previous years. Water levels were generally within or above the average range from January to May 2020. Water levels declined steadily, however, from July to September (fig. 5B). By September, 71 of 117 wells (61 percent) with measurements had water levels that were below average, 19 wells recorded the lowest monthly water level in the past 25 years, and 3 wells were dry.

Groundwater levels in Rhode Island were low in August and September, with water levels in 20 and 21 wells, respectively, out of 27 wells at or below the 25th percentile. In August, 3 wells had 25-year monthly low water levels, and in September, 12 wells had 25-year monthly low water levels. In Connecticut, water levels in all 19 wells analyzed were below the 50th percentile by July and 5 of 8 wells in the lower Connecticut River watershed were at or below the 25 th percentile. In September, water levels in 11 of 19 wells in Connecticut were below the 25 th percentile, and at 2 of these, water levels were also 25 -year record monthly lows. In Massachusetts, 21 of the 62 wells had monthly water levels at or the below the 25th percentile in July; 11 of these were in the lower Connecticut River watershed. In September, 32 of 62 wells ( 52 percent) in Massachusetts had water levels at or below the 25 th percentile. In Vermont, water levels at two of the three wells were below the 25th percentile from May through September. Both wells in New Hampshire had water levels below the 10th percentile by September, with one of these representing a 25 -year low for September. Three of the eight wells in Maine were at or below the 25th percentile in September (fig. 5B).

Out of four representative wells for monthly water levels with records between 36 and 80 years (fig. 6), three of the four wells (fig. 6A-C) had higher water levels in May 2020 than in May 2016; the water levels in each of these wells declined to below equivalent 2016 levels by September 2020. Two of the four wells (fig. $6 A$ and $D$ ) had record lows in September 2020.

\section{Paired Streamflow and Groundwater Responses to Drought}

Streamflows at streamgages and water levels at nearby wells generally followed similar downward trends throughout the 2020 drought. In the area between Dover-Foxcroft and Millinocket, Maine, the cumulative precipitation during water year 2020 exceeded 2.5 in. above average in early May, but by the end of September, water year precipitation deficits exceeded 4 in. (fig. 7). Although both streamflow and water levels declined through May and June, streamflow at the Piscataquis River near Dover-Foxcroft recovered slightly in July, and daily mean groundwater levels at a well in Millinocket remained below average because of limited groundwater recharge. 

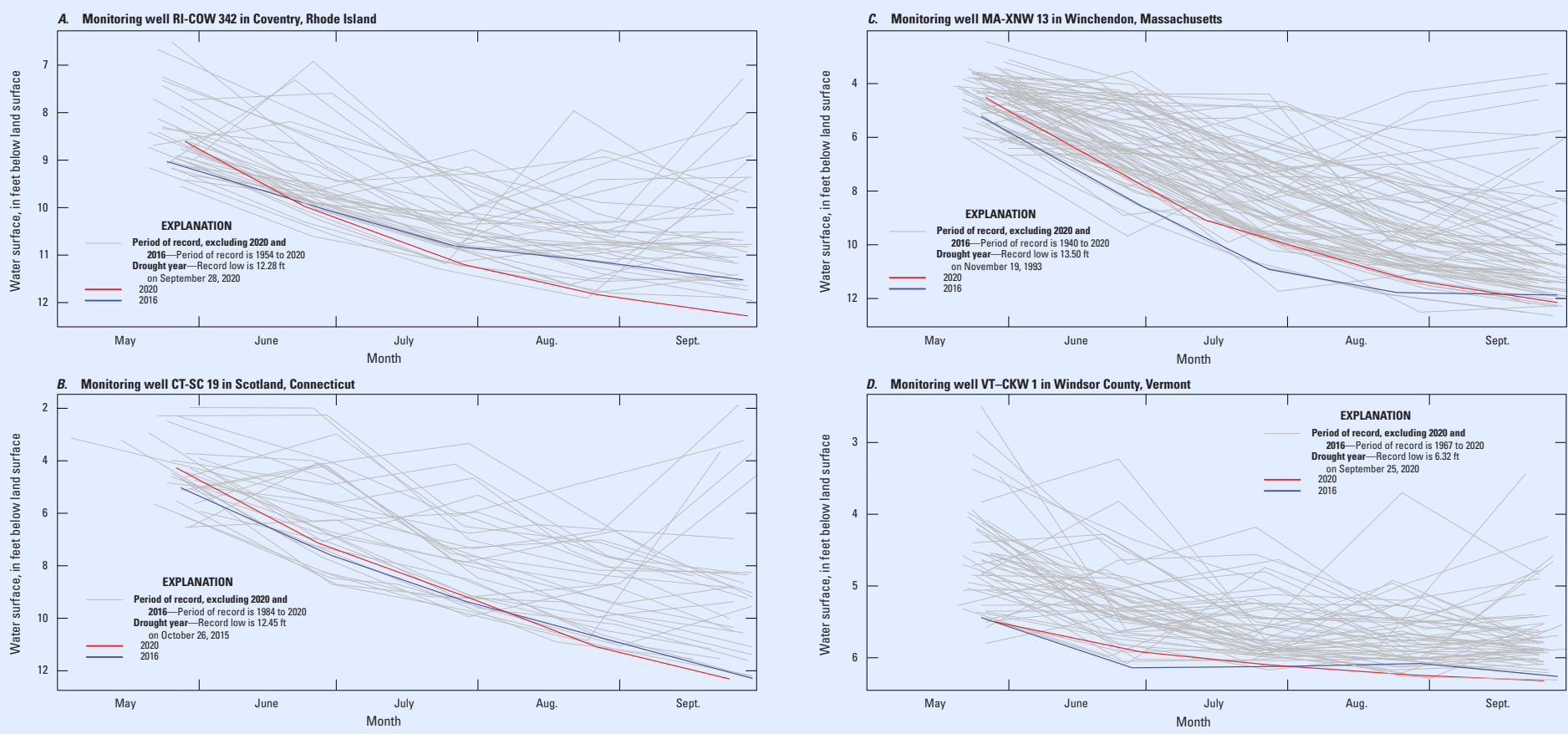

Figure 6. Graphs showing monthly groundwater levels at four monitoring wells in New England from May through September for their period of record. ft bls, foot below land surface. A large version of the figure is available at https://doi.org/10.3133/ofr20201148.

Similarly, in Hartford, the departure from average precipitation for water year 2020 ranged from 4 in. above average in early May to $5.4 \mathrm{in}$. below average by September 28. Streamflow conditions at Salmon River near East Hampton, Conn., and realtime water-level data at a well in Marlborough, Conn., followed a similar trend from above average conditions in May to below average conditions between June and September (fig. 8).

\section{Comparison of Streamflow Statistics to Previous Droughts}

Although it is challenging to compare the intensity and duration of droughts that can last from a couple of months to most of a decade, notable droughts in New England in the past 60 years include 1961-69, 1991, 1995, 1998-2002, 2016, and 2020. For the 1961-69 drought, June 1964 and July 1965 had more than 10 percent of the streamgages analyzed for this time period with period of record 7-day lows (table 1).

More than 10 percent of streamgages throughout New England had 30-year annual low flows in 1995 and 2020, as measured from the extreme level of the low flows in September for both years, the month which typically has the lowest flows of the year. More than 25 percent of streamgages had their lowest July flows in 30 years in 1991 and 2016; however, the drought of 1991 affected a large part of New England, whereas the 2016 drought primarily affected southern New England. The 1961-69 and 1998-2002 droughts were notable for their duration and for their wide geographic effects; the 1998-2002 drought was most severe in northern New England.
Table 1. Droughts in New England

\begin{tabular}{ll}
\hline \multicolumn{1}{c}{ Year } & \multicolumn{1}{c}{ Month (States severely affected) ${ }^{1}$} \\
\hline & 30-year lows at more than 10 percent of sites \\
\hline 1991 & June and July \\
1995 & June to September \\
1999 & May (Maine, New Hampshire, Vermont) \\
2001 & June to August \\
2002 & August to September \\
2016 & August to September \\
& June to August (Massachusetts, Rhode Island, \\
2020 & Connecticut) \\
\hline \multicolumn{2}{c}{ Period of record lows at more than 10 percent of sites } \\
\hline $1961-69$ & June 1964 and July 1965 \\
\hline
\end{tabular}

${ }^{1}$ Where no States are indicated, all States in New England were affected. 

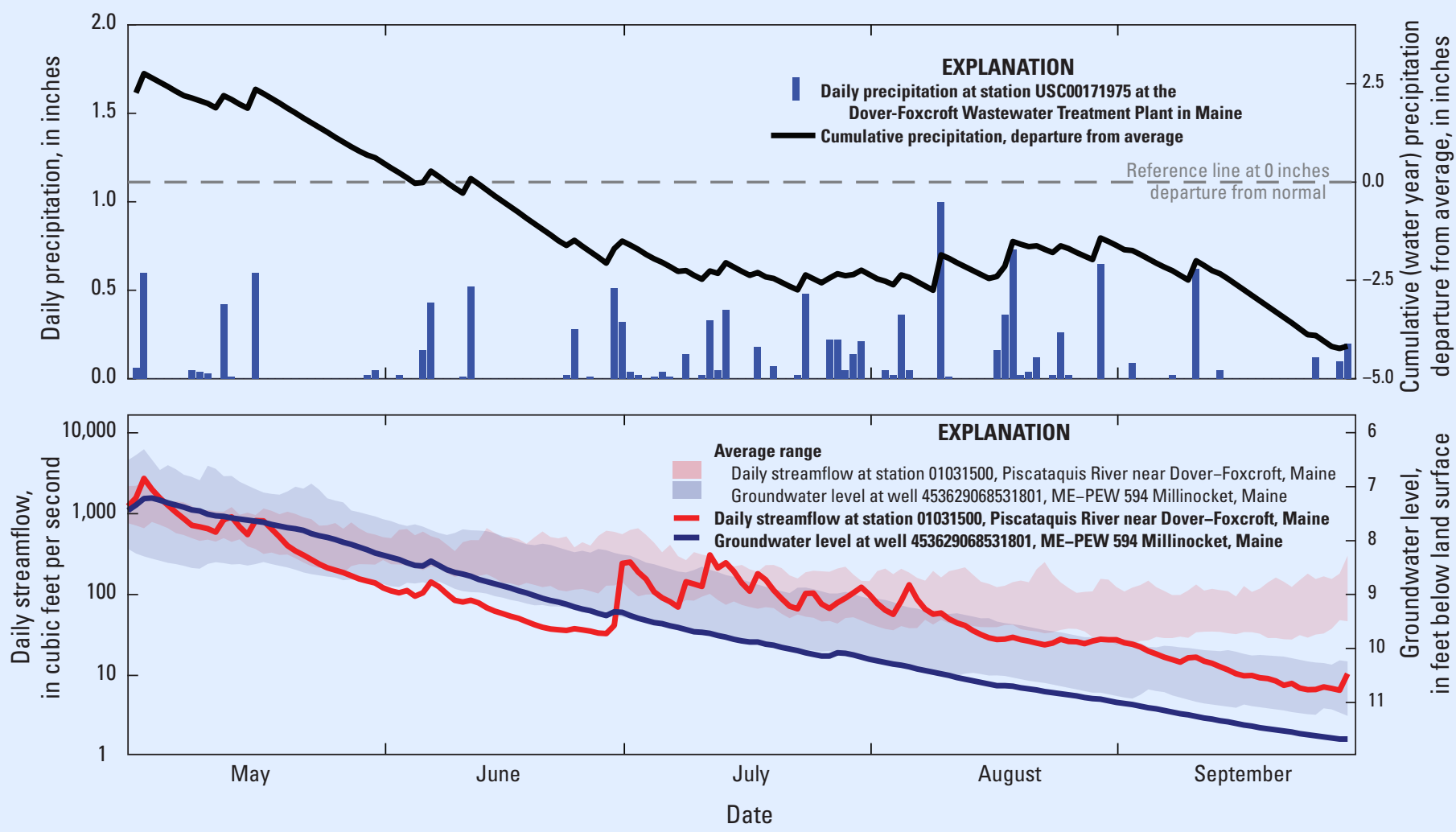

Figure 7. Graphs of conditions at Dover-Foxcroft, Maine, showing $A$, precipitation at National Weather Service station USC00171883 at the Dover Foxcroft wastewater treatment plant and B, streamflow at U.S. Geological Survey (USGS) streamgage 01031500 at the Piscataquis River near Dover-Foxcroft and groundwater level at USGS observation well 453629068531801 (station named ME-PEW 594) from May through September 2020. Averages were based on 30 years of data for precipitation and streamflow and on 25 years of data for groundwater levels.
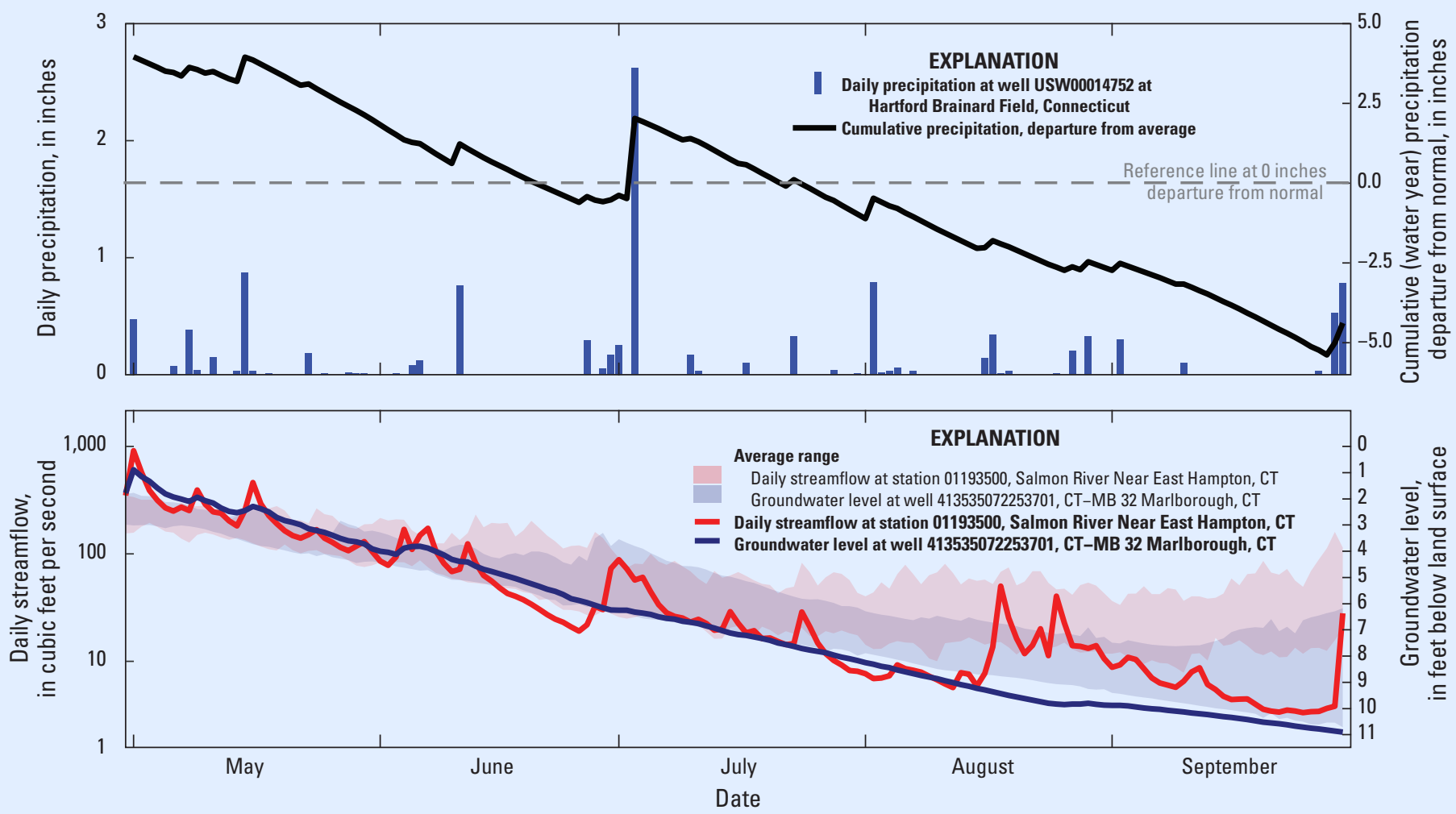

Figure 8. Graphs of conditions around East Hampton, Connecticut, showing $A$, precipitation from National Weather Service station USW00014752 at Hartford Brainard Field, Conn., and B, streamflow at U.S. Geological Survey (USGS) streamgage 01193500 at the Salmon River near East Hampton, Conn., and groundwater levels at USGS observation well 413535072253701 (station named CT-MB 32) in Marlborough, Conn., from May through September 2020. Averages were based on 30 years of data for precipitation and streamflow and on 25 years of data for groundwater levels. 


\section{Provisional Nature of the Data}

Many of the data presented in this report are provisional and subject to revision following formal quality-assurance review by the USGS, as indicated in NWIS (U.S. Geological Survey, 2020).

\section{Acknowledgments}

The authors thank the numerous partners, collaborators and stakeholders who cooperate with the USGS to maintain the network of streamflow and groundwater-level monitoring sites in New England. The authors thank Richard Kiah and Jeremy Foote of the USGS for their contributions to this report and the many hydrologic technicians of the USGS in New England for collecting the data that made this work possible.

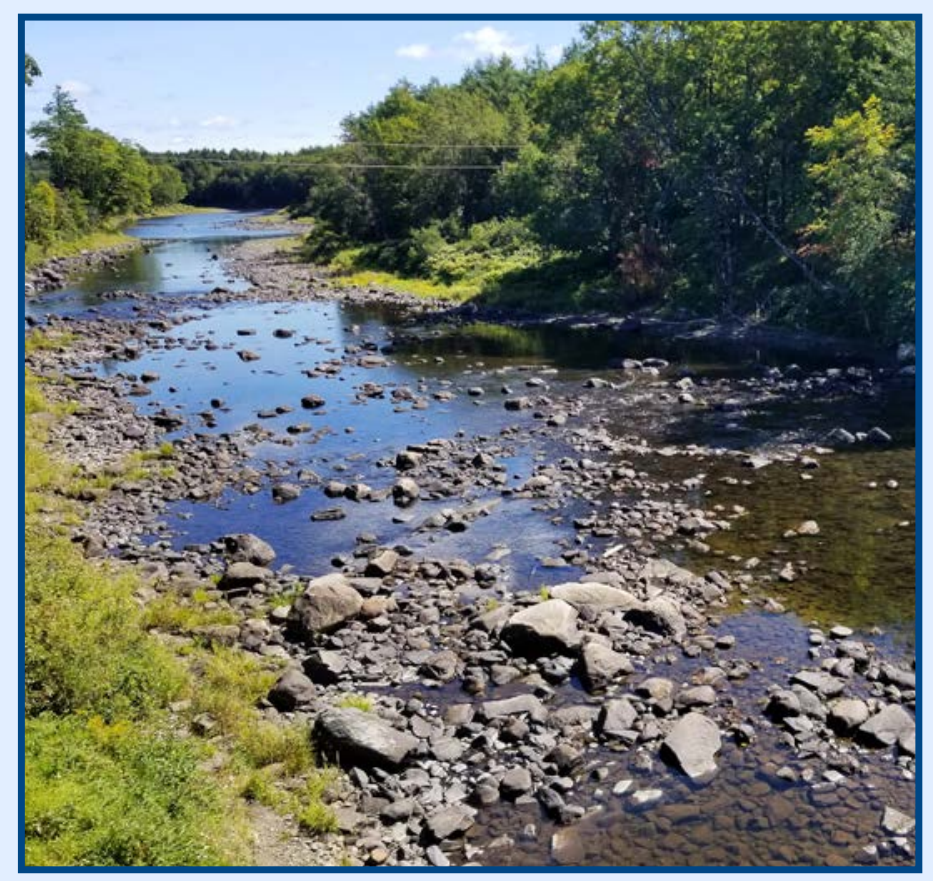

Photograph of low-flow conditions at the Piscataquis River near Dover-Foxcroft, Maine, at U.S. Geological Survey streamgage 01031500 on September 11, 2020; photograph by Andrew Cloutier, USGS.

\section{Summary}

Much of New England experienced hydrologic drought in summer 2020. The abrupt change in precipitation from at or above average in early May to as much as 4 in. below average in September 2020 and the resulting precipitous declines in streamflows and groundwater levels have been characterized as a flash drought (reflecting its quick onset) at some locations in New England, including northern Maine, southeastern Massachusetts, northern Rhode Island, and northeastern Connecticut. The 2020 drought rivaled other historic droughts, including those in 1995 and 1998-2002, in terms of intensity and geographic effects. Although streamflows and groundwater levels began to recover in October and November 2020, full recovery will depend on precipitation during the coming winter and spring.

\section{References Cited}

Cunningham, W.L., and Schalk, C.W., comps., 2011, Groundwater technical procedures of the U.S. Geological Survey: U.S. Geological Survey Techniques and Methods, book 1, sec. A1, 151 p. [Also available at https://doi.org/10.3133/tm1A1.]

Maine Geological Survey, 2020, Maine cooperative snow survey: Maine Geological Survey data, accessed October 8, 2020, at https://www.maine.gov/dacf/mgs/hazards/snow_survey/.

National Drought Mitigation Center, 2020, United States drought monitor: National Drought Mitigation Center data, accessed October 10, 2020, at https://droughtmonitor.unl.edu.

National Oceanic and Atmospheric Administration, 2020a, Climate at a glance-Divisional time series: National Oceanic and Atmospheric Administration National Center for Environmental Information dataset, accessed December 18, 2020, at https://www.ncdc.noaa.gov/cag/.

National Oceanic and Atmospheric Administration, 2020b, Evaporative demand drought index: National Oceanic and Atmospheric Administration data, accessed October 15, 2020, at https://www.psl.noaa.gov/eddi/.

National Oceanic and Atmospheric Administration, 2020c, National Weather Service climate services: National Oceanic and Atmospheric Administration data, accessed October 1, 2020, at https://w2.weather.gov/climate/.

National Oceanic and Atmospheric Administration, 2020d, Normal precipitation, inches: National Oceanic and Atmospheric Administration cooperative climatic data, accessed November 15, 2020, at https://www1.ncdc.noaa.gov/ pub/data/ccd-data/nrmpcp.txt.

New Hampshire Department of Environmental Services, 2020, Real-time data \& information for watersheds in New Hampshire: New Hampshire Department of Environmental Services data, accessed October 8, 2020, at https://www4.des.state. nh.us/rti_home.

Northeast Regional Climate Center, 2020a, Northeast drought assessments 2016-2017: Northeast Regional Climate Center web page, accessed December 16, 2020, at http://www.nrcc.cornell.edu/regional/drought/pubs/ assessment_2016.pdf.

Northeast Regional Climate Center, 2020b, Northeast drought update: Northeast Regional Climate Center web page, accessed November 19, 2020, at http://www.nrcc.cornell.edu/ regional/drought/drought.html.

Otkin, J.A., Svoboda, M., Hunt, E.D., Ford, T.W., Anderson, M.C., Hain, C., and Basara, J.B., 2018, Flash droughtsA review and assessment of the challenges imposed by rapid-onset droughts in the United States: Bulletin of the American Meteorological Society, v. 99, no. 5, p. 911-919, accessed October 22, 2020, at https://doi.org/10.1175/ BAMS-D-17-0149.1.

PRISM Climate Group, 2020, 30-year normal: PRISM Climate Group data, accessed November 15, 2020, at https://prism.oregonstate.edu/normals/. 
Rantz, S.E., and others, 1982, Measurement of stage and discharge, v. I of Measurement and computation of streamflow: U.S. Geological Survey Water-Supply Paper 2175, 284 p. [Also available at https://doi.org/10.3133/wsp2175.]

Svoboda, M., LeComte, D., Hayes, M., Heim, R., Gleason, K., Angel, J., Rippey, B., Tinker, R., Palecki, M., Stooksbury, D., Miskus, D., and Stephens, S., 2002, The drought monitor: Bulletin of the American Meteorological Society, v. 83 no. 8, p. 1181-1190, accessed December 22, 2020, at https://doi.org/10.1175/1520-0477-83.8.1181.

Turnipseed, D.P., and Sauer, V.B., 2010, Discharge measurements at gaging stations: U.S. Geological Survey Techniques and Methods, book 3, chap. A8, 87 p. [Also available at https://pubs.er.usgs.gov/publication/tm3A8.]

U.S. Department of Agriculture, 2020, USDA designates Aroostook County, Maine, as a primary natural disaster area: U.S. Department of Agriculture web page, accessed October 2, 2020, at https://www.fsa.usda.gov/news-room/ emergency-designations/2020/ed_2020_0911_rel_0188.

U.S. Environmental Protection Agency and U.S. Geological Survey, 2012, NHDPlus version 2.1: Horizon Systems web page, accessed October 12, 2020, at https://nhdplus.com/NHDPlus/ NHDPlusV2_home.php.

U.S. Geological Survey, 2020, USGS water data for the nation: U.S. Geological Survey National Water Information System database, accessed October 10, 2020, at https://doi.org/10.5066/F7P55KJN.

\section{Appendix 1. U.S. Geological Survey Streamgages and Groundwater Observation Wells Used To Analyze Drought Conditions in New England in 2020}

The data in these tables are replicated from the U.S. Geological Survey National Water Information System database (U.S. Geological Survey, 2020) and are available for download at https://doi.org/10.3133/ofr20201148

Table 1.1. U.S. Geological Survey streamgages used to analyze drought conditions in New England in 2020.

Table 1.2. U.S. Geological Survey groundwater observation wells used to analyze drought conditions in New England in 2020.

By Pamela J. Lombard, Janet R. Barclay, and Dee-Ann E. McCarthy

For more information, contact

Director, New England Water Science Center

U.S. Geological Survey

10 Bearfoot Road

Northborough, MA 01532

dc_nweng@usgs.gov

or visit our website at

https://www.usgs.gov/centers/new-england-water

Publishing support provided by the Pembroke and Reston Publishing Service Centers. 